\title{
Microbial diversity and impact on carbonate geochemistry across a changing geochemical gradient in a karst aquifer
}

\author{
Cassie J Gray ${ }^{1,2}$ and Annette S Engel ${ }^{1,3}$ \\ ${ }^{1}$ Department of Geology and Geophysics, Louisiana State University, Baton Rouge, LA, USA; ${ }^{2}$ CH2M Hill, \\ Baton Rouge, LA, USA and ${ }^{3}$ Department of Earth and Planetary Sciences, University of Tennessee, Knoxville, \\ TN, USA
}

\begin{abstract}
Although microbes are known to influence karst (carbonate) aquifer ecosystem-level processes, comparatively little information is available regarding the diversity of microbial activities that could influence water quality and geological modification. To assess microbial diversity in the context of aquifer geochemistry, we coupled 16S rRNA Sanger sequencing and 454 tag pyrosequencing to in situ microcosm experiments from wells that cross the transition from fresh to saline and sulfidic water in the Edwards Aquifer of central Texas, one of the largest karst aquifers in the United States. The distribution of microbial groups across the transition zone correlated with dissolved oxygen and sulfide concentration, and significant variations in community composition were explained by local carbonate geochemistry, specifically calcium concentration and alkalinity. The waters were supersaturated with respect to prevalent aquifer minerals, calcite and dolomite, but in situ microcosm experiments containing these minerals revealed significant mass loss from dissolution when colonized by microbes. Despite differences in cell density on the experimental surfaces, carbonate loss was greater from freshwater wells than saline, sulfidic wells. However, as cell density increased, which was correlated to and controlled by local geochemistry, dissolution rates decreased. Surface colonization by metabolically active cells promotes dissolution by creating local disequilibria between bulk aquifer fluids and mineral surfaces, but this also controls rates of karst aquifer modification. These results expand our understanding of microbial diversity in karst aquifers and emphasize the importance of evaluating active microbial processes that could affect carbonate weathering in the subsurface.
\end{abstract}

The ISME Journal (2013) 7, 325-337; doi:10.1038/ismej.2012.105; published online 15 November 2012

Subject Category: geomicrobiology and microbial contributions to geochemical cycles

Keywords: carbonate; Edwards Aquifer; geomicrobiology; groundwater; karst; microcosms

\section{Introduction}

Karst landscapes comprise $20-25 \%$ of the ice-free land surface (Ford and Williams, 2007), and nearly $20 \%$ of society worldwide relies on karst aquifers for economic, urban and environmental fresh water (Martin and White, 2008). Water movement into and through karst aquifers generally originates as meteoric water that enters the subsurface through sinkholes or fractures, and moves for some distance underground in conduit or diffuse-flow systems, with eventual resurgence at the surface as diffuse or spring discharge (White, 2002; Musgrove et al., 2009). Karst aquifers are unique among other

Correspondence: AS Engel, Department of Earth and Planetary Sciences, University of Tennessee, 1412 Circle Drive, Knoxville, TN 37996, USA.

E-mail: aengel1@utk.edu

Received 15 March 2012; revised 6 August 2012; accepted 6 August 2012; published online 15 November 2012 groundwater systems because they are self-developing, whereby dissolved bedrock constituents are transported through and out of the system (Ford and Williams, 2007). Karst aquifer modification can be affected by external mechanisms like climate change that alter the flux of meteoric water into the system (see, e.g., Loáiciga et al., 2000; Loáiciga, 2009), or from internal processes like chemical reactions and microbial activity (see, e.g., Engel et al., 2004). Although microbes have been shown to affect water quality and biogeochemical and ecosystem-level processes in other types of aquifers (Griebler and Lueders, 2009; Kato et al., 2009; Stein et al., 2010; Smith et al., 2011), there has been limited research to define microbial activities that affect aquifer karstification.

The Edwards Aquifer in Central Texas is one of the most significant karst aquifers in the world, supplying fresh water to nearly two million people (Sharp and Banner, 1997; Loáiciga et al., 2000). The aquifer system comprises distinct zones of fresh and 
saline water, with a transition zone ranging from $<1 \mathrm{~km}$ to $\sim 10 \mathrm{~km}$ in width (Groscehen and Buszka, 1997) that roughly coincides with major faulting in the Balcones Fault Zone (Supplementary Figure S1). Up-dip of the transition within the freshwater zone, the aquifer is unconfined, has high transmissivity $\left(\sim 190000 \mathrm{~m}^{-2}\right.$ day $\left.^{-1}\right)$ and relatively low total dissolved solids (TDS) from 250 to $300 \mathrm{mg} \mathrm{l}^{-1}$ (Groscehen and Buszka, 1997). Localized flow systems are complex and anisotropic because of faults, fractures and karstification that keep fresh water from extensively flushing into and through the down-dip, confined part of the aquifer where residence times of water and rock-water interactions increase (Groscehen and Buszka, 1997). The confined portion of the aquifer has much lower transmissivity $\left(\sim 1000 \mathrm{~m}^{-2}\right.$ day $\left.^{-1}\right)$ with TDS values $>1000 \mathrm{mgl}^{-1}$. Because an estimated $<10 \%$ of fresh water moves into and mixes with the saline water (Rye et al., 1981), the saline zone geochemistry is predominately influenced by structural and stratigraphic controls that affect cross-formational flow and mixing of brines from down-dip petroleum fields (Land and Prezbindowski, 1981; Clement and Sharp, 1988; Oetting et al., 1996).

The juxtaposition of these geochemically dissimilar waters results in a rich, diverse ecosystem, which Longley (1981) suggests may make the Edwards Aquifer the world's largest chemolithoautotrophically based karst system. Microbial activity is certainly important to the aquifer ecosystem. A prominent source of dissolved organic carbon in the aquifer is likely from microbial primary production (Birdwell and Engel, 2009), including from putative sulfur-oxidizing bacteria belonging to the Gammaproteobacteria (Thiothrix spp.) and uncultured Epsilonproteobacteria that were recently identified from white filamentous biomass in saline water wells (Engel and Randall, 2011). To determine if microbial diversity was associated with particular geochemical conditions, in this study we evaluated diversity and spatial distribution related to changing environmental conditions across the fresh to saline water transition zone in the Edwards Aquifer. We applied Sanger sequencing initially to reveal microbial diversity, and then used pyrosequencing to provide a higher-resolution analysis of community structure. To assess what impact, if any, the microbes had on aquifer carbonate geochemistry and potential modification through enhanced carbonate dissolution, we conducted in situ microcosm experiments in wells across the transition zone. Previous in situ microcosm experiments from karst systems have been restricted to sulfidic cave and aquifer conditions (see, e.g., Engel et al., 2004; Engel and Randall, 2011), whereby carbonate dissolution has been linked to colonization by putative sulfuroxidizing bacterial groups. The role of microbial colonization and activity on carbonate geochemistry and potential dissolution in freshwater karst systems has not been recognized. The results from our study demonstrate the importance of quantifying the extent to which microbes affect carbonate rock weathering in karst because microbially mediated dissolution may be more significant than previously considered.

\section{Materials and methods}

Water sample acquisition, aqueous geochemistry and geochemical modeling

Six nonpumping observation wells in Comal County, Texas, cross the fresh to saline water transition zone within $\sim 1 \mathrm{~km}$ (Supplementary Figure S1 and Table S1). The wells are completed within the Cretaceous Edwards Group carbonates and have the capacity to flow under artesian conditions. During the sampling time, water was pumped from the wells because of regional drought. For well sampling, we followed United States Geological Survey protocols (Wood, 1981; Koterba et al., 1995; US Geological Survey, http://pubs. water.usgs.gov/twri9A). Details are included in the Supplementary Materials and methods. Aqueous geochemical analyses and computational modeling provided saturation conditions for aquifer minerals, specifically calcite and dolomite. The saturation index (SI) of a mineral is defined as $\log \left(\mathrm{IAP} / K_{\mathrm{sp}}\right)$, where IAP is the ion activity product and $K_{\mathrm{sp}}$ is a mineral thermodynamic equilibrium constant. A positive SI value indicates that precipitation with respect to a mineral is thermodynamically possible, whereas negative SI values indicate dissolution. A SI of $0 \pm 0.5$ indicates a mineral is at equilibrium within the solution.

\section{Microbiological samples and molecular analyses}

Depending on pump rate, 13.5 to $18 \mathrm{l}$ water was run through GF/F filters (see Supplementary Materials and methods) at all of the transect wells and from a sulfidic saline well located $\sim 25 \mathrm{~km}$ north in San Marcos, called Aquarena (well LR-67-01-814). This well served as a saline end-member (Supplementary Figure S1a). Comal Springs was a freshwater endmember, and $27 \mathrm{l}$ water was filtered from it. All filters were aseptically cut into thirds and nucleic acids were extracted from each segment, following Fuhrman et al. (1988). Briefly, the triplicate DNA extractions were pooled for PCR amplifications to construct and screen 16S rRNA gene clone libraries based on Sanger sequencing of near-full-length genes (see Supplementary Materials and methods). The 16S rRNA gene sequences for clones from this study were deposited in GenBank under the accession numbers HM066203 to HM066729.

Composite DNA was also used for tag-encoded FLX Titanium amplicon pyrosequencing of $16 \mathrm{~S}$ rRNA genes, done by the Research and Testing Laboratories (RTL) in Lubbock, Texas, USA. RTL purified the DNA to remove PCR inhibitors and trace humic substances, and amplified fragments 
using 103F-530R primers (Dowd et al., 2008; Sun et al., 2011). Resulting pyrosequences were sorted based on RTL-provided barcodes to form different pyrosequence libraries corresponding to each sample. Raw sequence reads were quality checked, which included eliminating pyrosequences that did not match primers and were too short $(<200 \mathrm{nt})$ for analyses. Barcodes and adaptor sequences were removed from the pyrosequences and trimmed and aligned in the Ribosomal Database Project Pipeline using quality score files (http:// pyro.cme.msu.edu; Cole et al., 2009). Files with quality scores $<20$ were removed. The raw pyrosequence reads are available at the NCBI (National Center for Biotechnology Information) Sequence Read Archive under accession number SRA049429. For clone library sequences and pyrosequences, operational taxonomic units (OTUs) were defined by the furthest neighbor distance, ranging from $0 \%$ to $20 \%$ dissimilarity, using the mothur platform (see Supplementary Materials and methods).

\section{In situ microcosm experiments and microscopy}

Mineral-microbe interactions are difficult to evaluate, especially in aquifers. Therefore, to differentiate microbially induced processes from abiotic reactions acting on carbonate geochemistry, we used an in situ microcosm approach with reactive (i.e., able to be colonized by microbes), sterile (i.e., abiotic) and control calcite and dolomite chips (Hiebert and Bennett, 1992; Rogers et al., 1998). Microcosms were constructed, deployed and analyzed using a modified approach from Engel and Randall (2011) (see Supplementary Materials and methods). Briefly, microcosms contained fragments (chips) of either calcite or dolomite. For sterile microcosms, chips were placed into dialysis tubing (Spectra/Por 3, Spectrum Laboratories, Inc., Rancho Domniguez, CA, USA, 3.5 kDa molecular-weight cutoff). All mass measurements were to $\pm 0.008 \mathrm{mg}$. At the end of the experiments, wells were not purged and instead water was collected from the upper $\sim 20-30 \mathrm{~m}$ of well casing with a peristaltic pump to evaluate what geochemical changes, if any, occurred in the casing from the start of the experiments. In the field, at least one chip per mineral, per experiment and per well was preserved using the preservation technique of Vandevivere and Bevaye (1992). Chips were imaged by scanning electron microscopy and energy-dispersive X-ray analysis (Engel and Randall, 2011). Putative cell densities on surfaces were quantified by systematically viewing 100 frames in a grid at $\times 5000$ over an area of $0.0625 \mathrm{~mm}^{2}$ per chip.

\section{Data analysis}

Pyrosequence data provided a semiquantitative assessment of the $\alpha$-diversity for each of the wells, and these data were used to establish whether variations in relative community changes at each well (i.e., $\beta$-diversity) corresponded to environmental variables and overall carbonate geochemistry (see, e.g., Legendre et al., 2005). Presence and absence results at the levels of phyla through genera, where classification was possible, were collated. Abundance data were normalized for each sample, and Euclidean distances were used to generate a hierarchical cluster analysis (Anderson, 2001). Statistical analyses were carried out using PAST software version 2.14 for Windows (Hammer et al., 2001). Environmental variables were $\log _{10}(x+1)$ transformed to correct skewness (Ramette, 2007). Geochemical correlations to taxonomic diversity were done with pre-experiment water compositions. Pearson's correlations ( $r$ values) were determined to measure the strength of linear relationships. Because of the potential that diversity was affected by a combination of interacting environmental variables, instead of responding to a single variable, nonparametric multivariate analysis of variation tests of significance between groups of geochemical data for each sample were calculated. Relationships between major taxonomic groups and environmental factors (e.g., pH, TDS, alkalinity, nitrate and so on) were analyzed by stepwise canonical correspondence analysis (CCA) that sequentially removed the least important variables, and maximized correlations between principal axes and linear combinations of environmental variables (Legendre and Legendre, 1998). Unimodal analyses were suitable because of the high occurrence of zero abundances (Ramette, 2007). Permutation tests were carried out. For all analyses, a $P$-value of $<0.05$ was considered to be significant, and values between 0.05 and 0.1 were considered marginally significant.

\section{Results}

Well and spring geochemistry

The study wells in New Braunfels, Texas, are completed in Edwards Group carbonates within the Comal Springs artesian fault block (Johnson and Schindel, 2008), but the Girl Scout wells are separated from the LCRA and Paradise Alley wells by a near-vertical minor fault with $\sim 25-30 \mathrm{~m}$ offset (Guyton, 1979) (Supplementary Figure S1c). This separation could affect hydrological communication between the wells, but the Girl Scout and LCRA wells, with Comal Springs, had water with TDS $<1000 \mathrm{mgl}^{-1}$ and Ca-Mg- $\mathrm{HCO}_{3}^{-}$type, whereas the Paradise Alley wells had TDS $>1000 \mathrm{mgl}^{-1}$ with Ca-Cl-SO ${ }_{4}^{2-}$-type water. Preexperiment water chemistry was used for all analyses because this was considered to be aquifer geochemical conditions from which the microbial communities were sampled (Table 1). Based on nonparametric multivariate analysis of variation clustering by salinity, geochemical shifts across the transition zone were noted for $\mathrm{pH} \quad(\mathrm{F}=10.59$, $P$-value $=0.04)$, alkalinity $(\mathrm{F}=4.26, P$-value $=0.05)$, 


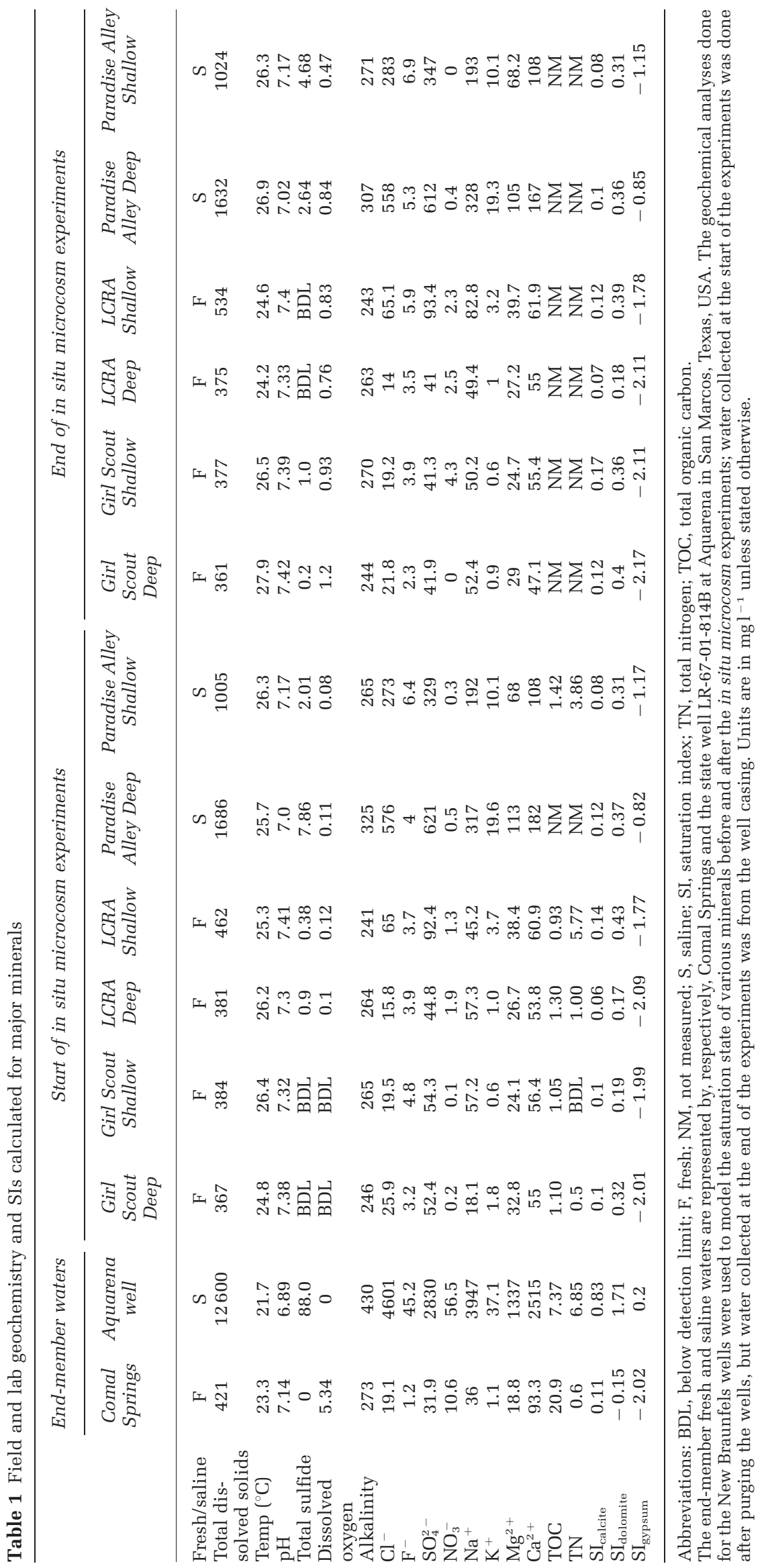


sulfide $(\mathrm{F}=3.05, P$-value $=0.02)$, Ca concentration $(\mathrm{F}=2.23, P$-value $=0.02)$ and sulfate concentration $(\mathrm{F}=4.45, P$-value $=0.02)$. All other parameters were insignificantly different across the transition zone. In general, freshwater wells had slightly higher $\mathrm{pH}$ values compared with saline waters, but bicarbonate concentrations were slightly higher for the saline, sulfidic wells. All well solutions were in equilibrium or supersaturated with respect to calcite (SI $=0.06$ to 0.14 ) and dolomite ( $\mathrm{SI}=0.17$ to 0.43 ), and all waters were undersaturated with respect to gypsum (Table 1).

\section{Taxonomic diversity}

Bacterial diversity was initially evaluated from Sanger sequencing to gain phylogenetic insight into community composition and to reveal possible taxonomic affiliations with cultured organisms. Although pyrosequencing allows for a more comprehensive sampling of diversity, taxonomic resolution is generally lower (Liu et al., 2008). Full descriptions of the taxonomic data are included in Supplementary Table S2 for Sanger sequences and Supplementary Table S3 for pyrosequencing results.

Among the clone libraries, 527 16S rRNA gene sequences were retrieved $(86 \%$ were $>1400 \mathrm{bp}$ in length), belonging to seven major phyla that comprised 143 OTUs classified at 98\% sequence identity. Proteobacteria dominated all clone libraries, ranging from $69 \%$ to $98 \%$ of the clones depending on well. Bacteroidetes ranged from $1 \%$ to $18 \%$ of all clones per well, Firmicutes from $0 \%$ to $5 \%$ and Planctomycetes from $0 \%$ to $2 \%$. Onequarter of the OTUs comprised clones from more than one well (Supplementary Table S2). A high percentage of the clones could be categorized taxonomically to genus, but $\sim 28 \%$ of the OTUs had $<95 \%$ sequence identity (and as low as $80 \%$ ) to previously cultured bacteria or other environmental clones, suggesting potentially novel diversity.

In all, 17 major taxonomic groups, including candidate divisions, were identified from 15074 pyrotags (average $2308 \pm 1201$ reads per sample, with an average length of $452 \mathrm{bp}$ ) from all wells and geochemical end-members (Table 2). Coverage based on rarefaction curves (Supplementary Figure S2) and Chao1 estimates (Table 2) was moderately saturated for the wells but undersaturated for the Comal Springs sample. The relative abundances of unclassified groups were relatively high for some wells, agreeing with the potentially novel diversity indicated from the clone libraries (Table 3). Many communities had relatively high Simpson's Dominance estimator values (Table 2) that was consistent with the prevalence of proteobacterial classes or bacilli (Firmicutes) for each of the waters (Table 3 and Figure 1).

Among the Proteobacteria, clone sequences and pyrosequences affiliated with the Alphaproteobacteria were retrieved from all wells and Comal Springs, despite pyrosequences affiliated with this class dominating only the Paradise Alley Deep well and being prevalent from Paradise Alley Shallow (Table 3). From clone libraries, two OTUs were common to the transect wells, both being closely related to the Caulobacteraceae Brevundimonas vesicularis (98-99\% sequence identity). Another OTU within the Caulobacteraceae, closely related to Caulobacter crescentus (99\% sequence identity), was common to four wells. Clone sequences affiliated with the genus Sphingomonas were also retrieved from all wells. From the clone libraries, Girl Scout Deep and Paradise Alley Shallow shared an OTU that was most closely related to uncultured Alphaproteobacteria (99\% sequence similarity) isolated from the sulfidic Lower Kane Cave, Wyoming, USA (Engel et al., 2010). In contrast, pyrosequence results showed that Caulobacteraceae were rare $(<0.3 \%$ of all pyrosequences for any sample), Sphingomonadales were only retrieved from freshwater wells and Comal Springs, and representation by Rhodospirillales or Rhizobiales families was higher (up to 12\%) in all wells (Supplementary Table S3). Previously, Engel and Randall (2011) uncovered novel alphaproteobacterial diversity within the Rhizobiales from a well $\sim 39 \mathrm{~km}$ north in New Braunfels, having TDS $>17000 \mathrm{mg} \mathrm{l}^{-1}$. Clone

Table 2 Diversity and richness estimators for pyrosequence libraries

\begin{tabular}{|c|c|c|c|c|c|c|}
\hline Sample & $\begin{array}{l}\text { Unique } \\
\text { sequences }\end{array}$ & $\begin{array}{l}96 \% \\
\text { OTUs }\end{array}$ & $\begin{array}{l}\text { Percentage of } \\
\text { singletons }\end{array}$ & $\begin{array}{l}\text { Chao1 } \\
\text { (mean) }\end{array}$ & $\begin{array}{c}\text { Shannon diversity } \\
\left(H^{\prime}\right)\end{array}$ & $\begin{array}{c}\text { Simpson's dominance } \\
\text { (D) }\end{array}$ \\
\hline Comal Springs & 4333 & 1662 & 71 & 4730 & 6.3 & 126.2 \\
\hline Girl Scout Deep & 2367 & 540 & 64 & 1321 & 4.5 & 17.6 \\
\hline Girl Scout Shallow & 2192 & 671 & 72 & 2166 & 5.0 & 26.9 \\
\hline LCRA Deep & 1937 & 650 & 66 & 1712 & 5.4 & 66.3 \\
\hline LCRA Shallow & 2111 & 772 & 65 & 1835 & 5.8 & 149.7 \\
\hline Paradise Alley Deep & 186 & 83 & 73 & 348 & 3.6 & 11.5 \\
\hline $\begin{array}{l}\text { Paradise Alley } \\
\text { Shallow }\end{array}$ & 1948 & 628 & 61 & 1404 & 5.5 & 77.1 \\
\hline Aquarena well & 3389 & 611 & 48 & 989 & 5.0 & 32.4 \\
\hline
\end{tabular}

Abbreviation: OTU, operational taxonomic unit.

Singletons were determined to be pyrosequence reads that only occurred once per sample. 


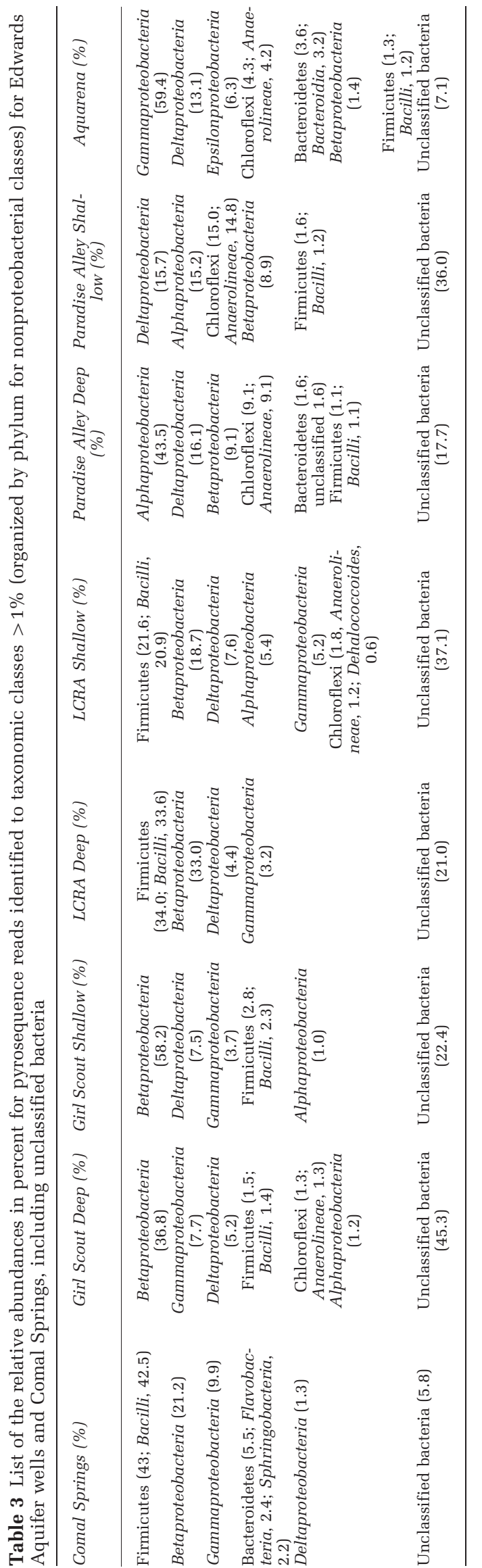

sequences and pyrosequences affiliated with the Gammaproteobacteria were retrieved from Comal Springs and all wells except Paradise Alley Deep. Gammaproteobacteria dominated the Aquarena well community (Table 3). Six clone-designated OTUs were common to four wells, with three OTUs being affiliated with different Pseudomonas spp. The other three OTUs were affiliated with groundwater or marine sand environmental clones (Supplementary Table S2). From the pyrosequences, Pseudomonadales were prevalent in all transect wells and Comal Springs. At Aquarena, 51\% of the pyrosequences were affiliated with unclassified Chromatiales within the Halothiobacillaceae order (Supplementary Table S3). Clone sequences affiliated with the Betaproteobacteria were identified in all wells, and the Burkholderiales, Rhodocyclales and Hydrogenophilales orders were evenly represented from the pyrosequence results. Betaproteobacteria dominated the Girl Scout well communities (Table 3). Among the Burkholderiales, their relative abundance from the pyrosequencing data was higher in wells with higher nitrate concentrations. LCRA Deep and Shallow shared an OTU most closely related to uncultured Rhodocyclales within the genus Azospira (99\% sequence identity). One clone-based OTU was affiliated with the Hydrogenophilales, specifically the genus Thiobacillus (99\% sequence identity). More pyrosequences affiliated with this genus were retrieved from high TDS and sulfidic wells, like Paradise Alley Shallow, although low numbers of pyrosequences were also retrieved from wells with lower TDS but with sulfide in the well casings after the microcosm experiments. Among the Deltaproteobacteria, which was the second most abundant group in three well communities from pyrosequence reads (Table 3), nine clone-based OTUs comprising one clone each were retrieved that confirmed broad diversity. Familial- to genuslevel taxonomic variations were noted, such that Desulfarculales (e.g., Desulfarculus) and Desulfovibrionales (e.g., Desulfovibrio) were prevalent in freshwater wells, but Desulfobacterales (e.g., Desulfonema) were prevalent in sulfidic wells.

Firmicutes, specifically from the Bacilli class, dominated pyrosequence-based communities in the LCRA wells and Comal Springs (Table 3). However, Firmicutes accounted for only $1.5 \%$ of all clone sequences. One OTU was related to uncultured Firmicutes spp. isolated from groundwater, and two others were most closely related to Vulcanibacillus modesticaldus, an anaerobic, nitrate-reducing bacterium isolated from deep-sea hydrothermal vents (L'Haridon et al., 2006). Four clone sequences were from LCRA Deep and Girl Scout Shallow (Supplementary Table S2). Other taxonomic groups had lower relative abundances, at or $<1.5 \%$ of the pyrosequences for each well, including Planctomycetes, Chloroflexi, Bacteroidetes and others (Table 3 and Supplementary Table S3). 


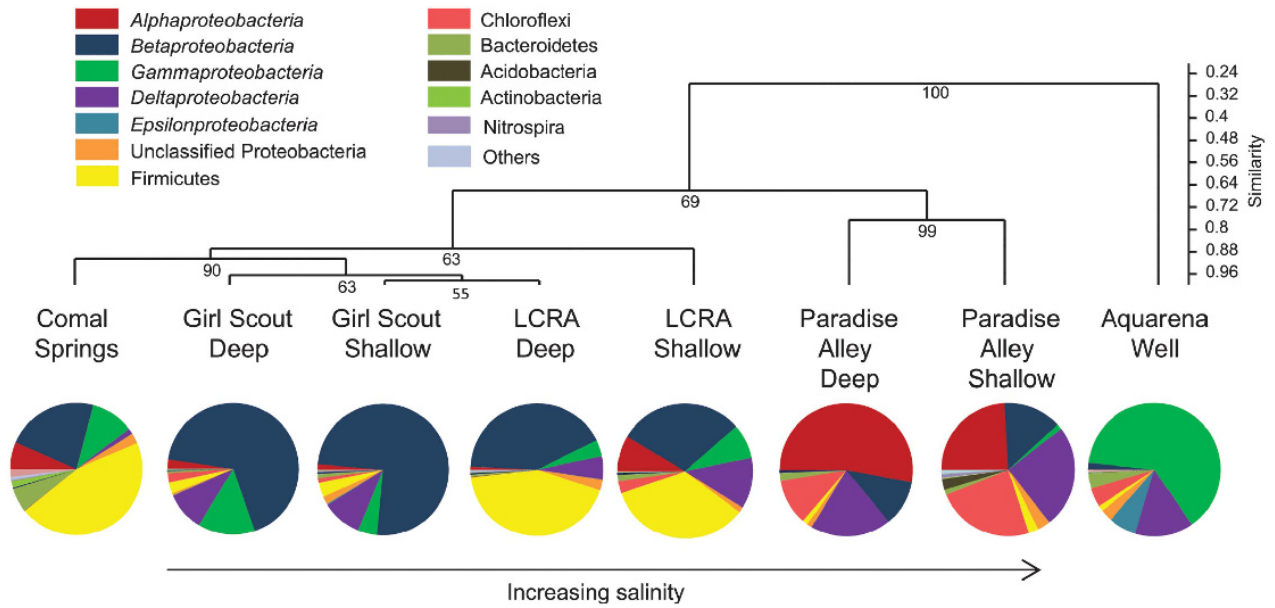

Figure 1 A dendrogram from hierarchical cluster analysis of eight sites based on a Bray-Curtis matrix of dissimilarities between sites, corresponding (from the left to right) to the order of wells in the transect of fresh water to saline water wells across the transition zone, as shown in Supplementary Figure S1. The relative abundances of pyrosequences classified to the class level for Proteobacteria and phylum level for other classifications are shown for descriptive purposes. Unclassified bacterial pyrosequences are not included. Cluster robustness was evaluated by bootstrapping.

Community differences across the transition zone A Bray-Curtis matrix of dissimilarities between sites with a high (0.87) cophenetic coefficient indicated there were differences in community composition across the transition zone (Figure 1). Freshwater wells were compositionally more similar to each other than to saline wells, and the composition of the Aquarena community was distinct. There was a high degree of similarity between the LCRA wells and Comal Springs (Figure 1). Although specific taxonomic groups had varying relative pyrosequence abundances (Table 3), and clone library results suggested shared taxa (Supplementary Table S2), the abundances of Betaproteobacteria (nonparametric multivariate analysis of variation $F=6.73$, $P$-value $=0.02), \quad$ Deltaproteobacteria $\quad(\mathrm{F}=6.18, \quad P$ value $=0.03)$ and Gammaproteobacteria $(\mathrm{F}=3.51$, $P$-value $=0.02)$ were statistically different between fresh and saline waters. Similarly, the relative abundances of Chloroflexi were statistically different $(\mathrm{F}=5.14, \quad P$-value $=0.02)$, with higher abundances in saline wells. The abundances of Firmicutes were also significantly different $(\mathrm{F}=15.4, \quad P$-value $=0.04) . \quad$ Interestingly,$\quad$ higher calcium concentrations significantly (Pearson's $r=-0.75)$, and alkalinity marginally $(r=-0.53)$, correlated to lower percentages of OTUs represented by only one pyrosequence per sample (Table 2). This may suggest that these geochemical parameters influence lower community diversity or that communities influenced by these geochemical parameters were dominated by fewer microbial groups.

The relationship between pyrosequence diversity and geochemistry was verified by CCA (Figure 2), such that the ordination of major taxonomic groups was strongly correlated to environmental variables. Communities were clearly separated by water type and $\sim 75 \%$ of the variance could be described by the first two axes of the final CCA obtained (Table 4).

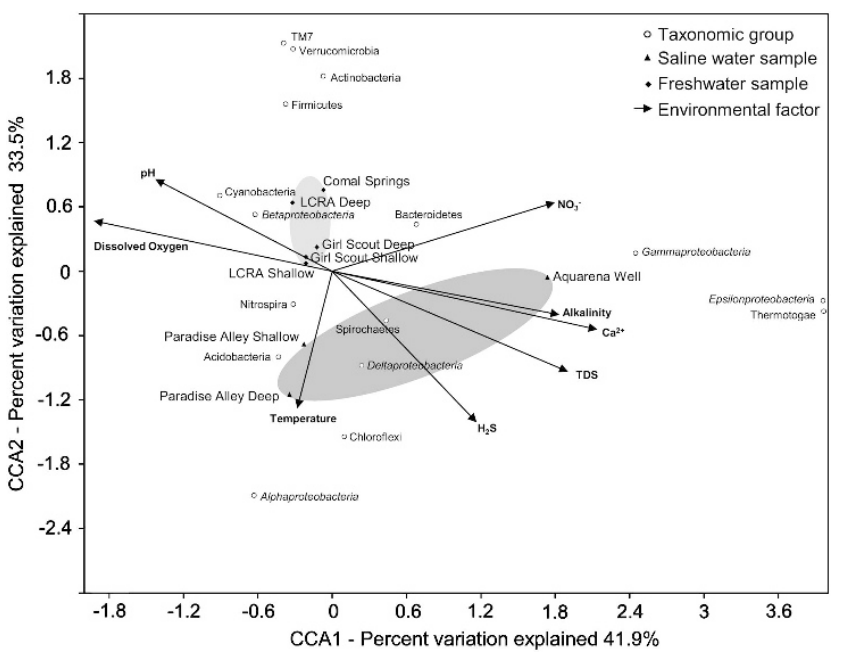

Figure 2 A triplot generated from CCA of 16S rRNA pyrosequence data showing the relationships among well water diversity, ordination of major taxonomic groups, either at the phylum or class level, and eight physicochemical variables, noted by labeled vectors (99999 Monte Carlo permutations, global $P$-value 0.003).

CCA axis 1 positively correlated to calcium concentration and alkalinity, which are interrelated variables associated with carbonate geochemistry, as well as TDS and sulfide, and negatively to oxygen. Saline waters had higher concentrations of calcium, alkalinity and TDS, with no measured dissolved oxygen. CCA axis 2 positively correlated to $\mathrm{pH}$ and negatively to temperature and sulfide concentration. CCA axis 3 positively correlated to nitrate and negatively to temperature.

\section{Experimental carbonate dissolution}

Bulk fluids alone should not be capable of dissolving the minerals because the aquifer waters were in 
Table 4 Correlations between each of the statistically significant CCA axes and the environmental variables from Figure 2

\begin{tabular}{lrrr}
\hline & Axis 1 & Axis 2 & Axis 3 \\
\cline { 2 - 4 } Variance & $41.9 \%$ & $33.5 \%$ & $19.4 \%$ \\
\hline P-value & 0.06 & 0.04 & 0.02 \\
\hline Calcium concentration & 0.94 & -0.27 & 0.17 \\
Dissolved oxygen concentration & -0.90 & 0.23 & 0.22 \\
Total dissolved solids & 0.85 & -0.47 & 0.17 \\
Temperature & -0.14 & -0.65 & -0.63 \\
pH & -0.66 & 0.42 & -0.56 \\
Alkalinity & 0.80 & -0.21 & 0.33 \\
Nitrate concentration & 0.78 & 0.30 & 0.52 \\
Sulfide concentration & 0.49 & -0.68 & -0.38 \\
\hline
\end{tabular}

Abbreviation: CCA, canonical correspondence analysis.

equilibrium or supersaturated with respect to calcite and dolomite (Table 1 and Figure 3a). However, chips from reactive in situ microcosms lost $12.5 \mathrm{mg}$ on average $(n=40)$ in the 26 days, which was statistically more mass compared with sterile chips for both minerals from both fresh and saline waters (all $P$-values < 0.05) (Supplementary Table S4). Control chips had insignificant mass changes, with a $0.01 \%$ average mass change for calcite $(P$-value $=$ $0.26)$ and for dolomite $(P$-value $=0.35)$, and within the s.d. of the experimental sterile chip mass losses from pre- and post-experiments ( $P$-value $>0.05$; Figure 3c). Greater mass loss for the reactive microcosms significantly correlated to higher SI values, although correlation values were more significant for calcite than dolomite (Figures 4a and d). Mass loss also increased with decreasing cell numbers (Figures $4 \mathrm{~b}$ and e), but lower cell numbers also negatively correlated to SI values (Figures 4c and f). Cells on calcite and dolomite chips were nonrandomly distributed, had diverse morphologies, regularly formed clusters with distinct attachment structures, were associated with varying amounts of extracellular polysaccharide material and were observed near features like cleavage plane structures and kinks or dissolution pits (Figure 5). The number of putative cells observed on reactive surfaces (Figure $3 \mathrm{~b}$ ) extrapolated to $10^{6}-10^{7}$ cells per chip. Chip surfaces, with or without cell associations, also had secondary precipitates, identified from energy-dispersive X-ray analysis as being ironsulfur-bearing (i.e., pyrite) and silica-bearing minerals (Supplementary Figure S3). Their importance is unknown because computer modeling of bulk aquifer fluids did not indicate fluids would be supersaturated with respect to such minerals.

\section{Discussion}

Carbonate dissolution is the consequence of integrated diffusion- and surface-controlled processes

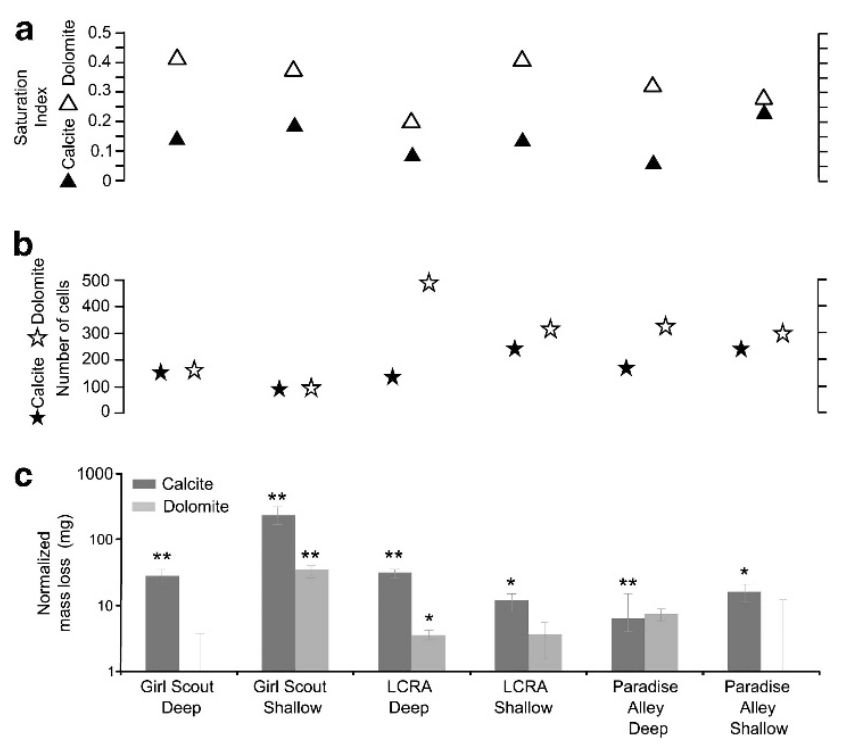

Figure 3 (a) Saturation indices for calcite (closed triangle) and dolomite (open triangle) versus (b) the average number of cells observed on the chip for calcite (closed star) and dolomite (open star) (surface area $=0.0625 \mathrm{~mm}^{2}$ ). (c) Normalized mass loss for calcite (dark gray) and dolomite (light gray) reactive microcosms in $\mathrm{mg}$ for each of the wells. Statistically significant differences between pre- and post-experiment loss are noted for $P$-values $\leqslant 0.05$ to $>0.01$ with one asterisk $\left({ }^{*}\right)$, or two asterisks $(* *)$ for $P$-values $\leqslant 0.01$ based on Student's $t$-tests.

that affect ion activities and the partial pressure of $\mathrm{CO}_{2}$, as well as mineral surface reactivity (see, e.g., Sjoberg and Rickard, 1984). Microbial processes focused at water-rock interfaces can significantly affect karstification and the flux of dissolved constituents through and out of the system, especially when solutions are near-equilibrium with bedrock minerals (Compton and Pritchard, 1990; White, 1997; Ehrlich and Newman, 2009). Although changes in microbial community composition from karst springs has been linked to storm-induced flow conditions (see, e.g., Pronk et al., 2009), and cave microbial diversity can determine potential transport history through karst (Shabarova and Pernthaler, 2010), quantification of microbial controls on geochemistry and potential karst aquifer modification has been limited. In this study, we expand our previous work (Engel et al., 2004; Engel and Randall, 2011) to expose a persistent link between geochemistry and microbial community composition from wells that cross the fresh to saline water transition zone in the Edwards Aquifer. Carbonate geochemistry, as well as the presence of variables used or produced metabolically (e.g., oxygen, sulfide), significantly explain the nonrandom distribution of microbial groups.

Our in situ microcosm experiments show that carbonate mass loss increased for chips that were colonized by microbes, which is similar to previous findings for the saline water zone in the Edwards Aquifer (Engel and Randall, 2011). However, 

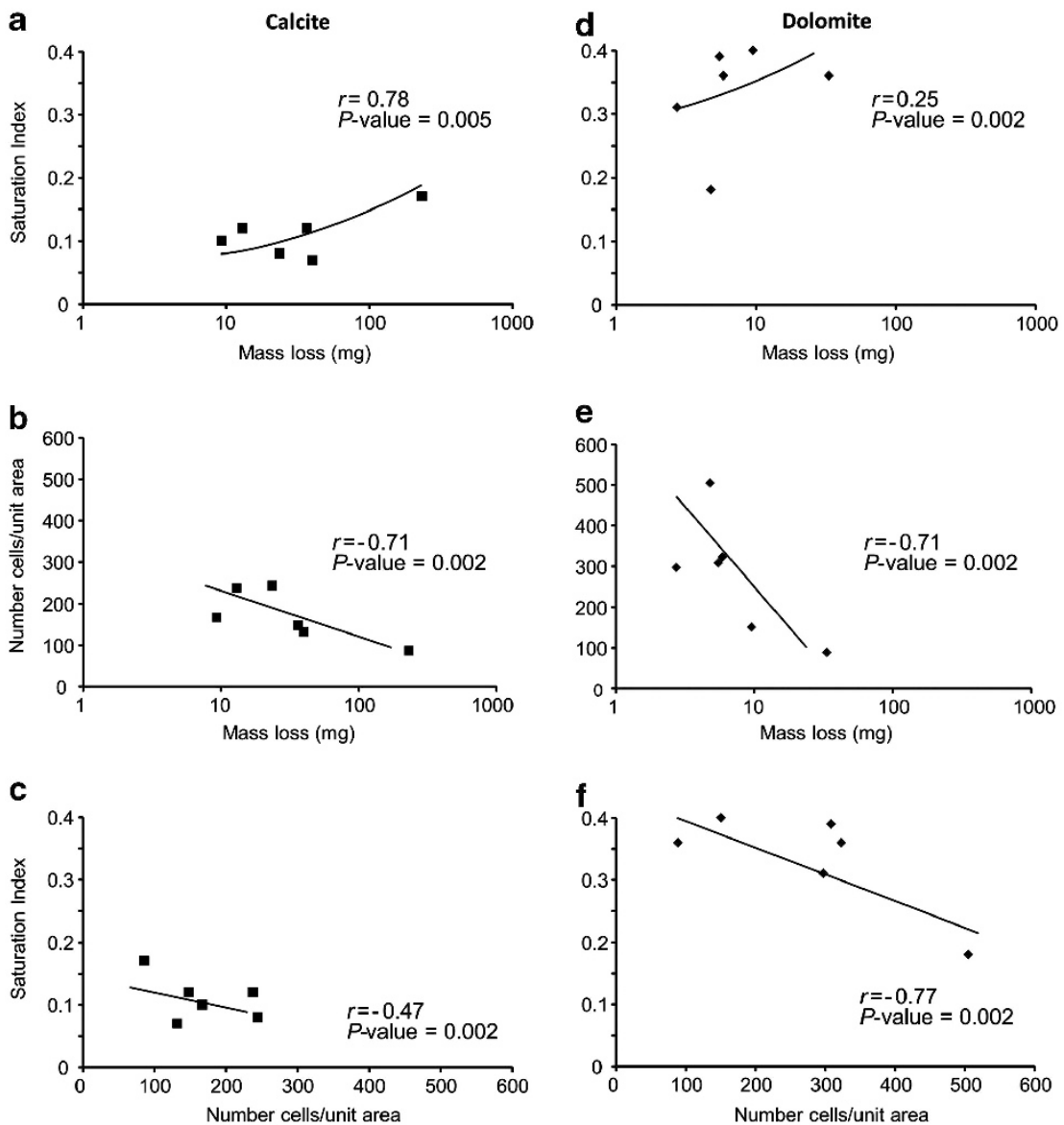

Figure 4 Summary of Pearson's correlation coefficients ( $r$ values) for comparisons of saturation indices, mass losses and numbers of cells per unit area for in situ microcosm experiments for calcite (a-c) and dolomite (d-f) minerals.

because we estimated cell densities on the surfaces for the current study, mass loss could be evaluated in terms of cell density. Results differed for calcite and dolomite and between saline and freshwater wells in the transect (Figure 3c). Dolomite had higher cell abundances compared with calcite, which Davis and Lüttge (2005) suggest may be because of dolomite having more energetically favorable sites for cell attachment than calcite. However, more cells did not necessarily result in greater dissolution as chips from saline, sulfidic wells had higher cell counts but lower mass loss compared with chips from freshwater wells. For saline wells, suppressed dissolution could be due to biofilm formation because biofilms create thermodynamic disequilibria between the bulk fluid and mineral surface that can slow surface retreat (Lüttge and Conrad, 2004; Davis and Lüttge, 2005; Engel and Randall, 2011). Because some microbes are biofilm formers, whereas others favor planktonic growth (see, e.g., Besemer et al., 2012), fewer cells on freshwater surfaces may be due to a higher proportion of microbes that prefer planktonic growth, or of cells less likely to attach to surfaces or of communities having slower attachment rates during the experiments. Certainly, regarding the natural system, planktonic cells, which are predominately sampled from well water, may not be attached to and colonizing aquifer surfaces where mineral-microbe interactions are presumably focused.

The distinct spatial distribution of certain microbial groups across the transition zone allows us to explore how carbonate solubility could be affected by specific microbial metabolic pathways present in the wells. It almost goes without saying that interpreting metabolism from taxonomic assignments is problematic and can be highly speculative, especially from pyrosequence results where a large fraction of the microbial community could not be resolved taxonomically. Therefore, our interpretations originate from environmental geochemistry and conservative phylogenetic analyses of clones that were closely related to previously cultured organisms and that can be framed in the context of pyrosequencing results. At present, we lack information that directly probes metabolic status and/or taxonomy, such as from lipid- or RNA-based analyses or fluorescence in situ hybridization, but this is the direction of future work. In the current study, in addition to the strong correlations to carbonate geochemistry, the community distribution 

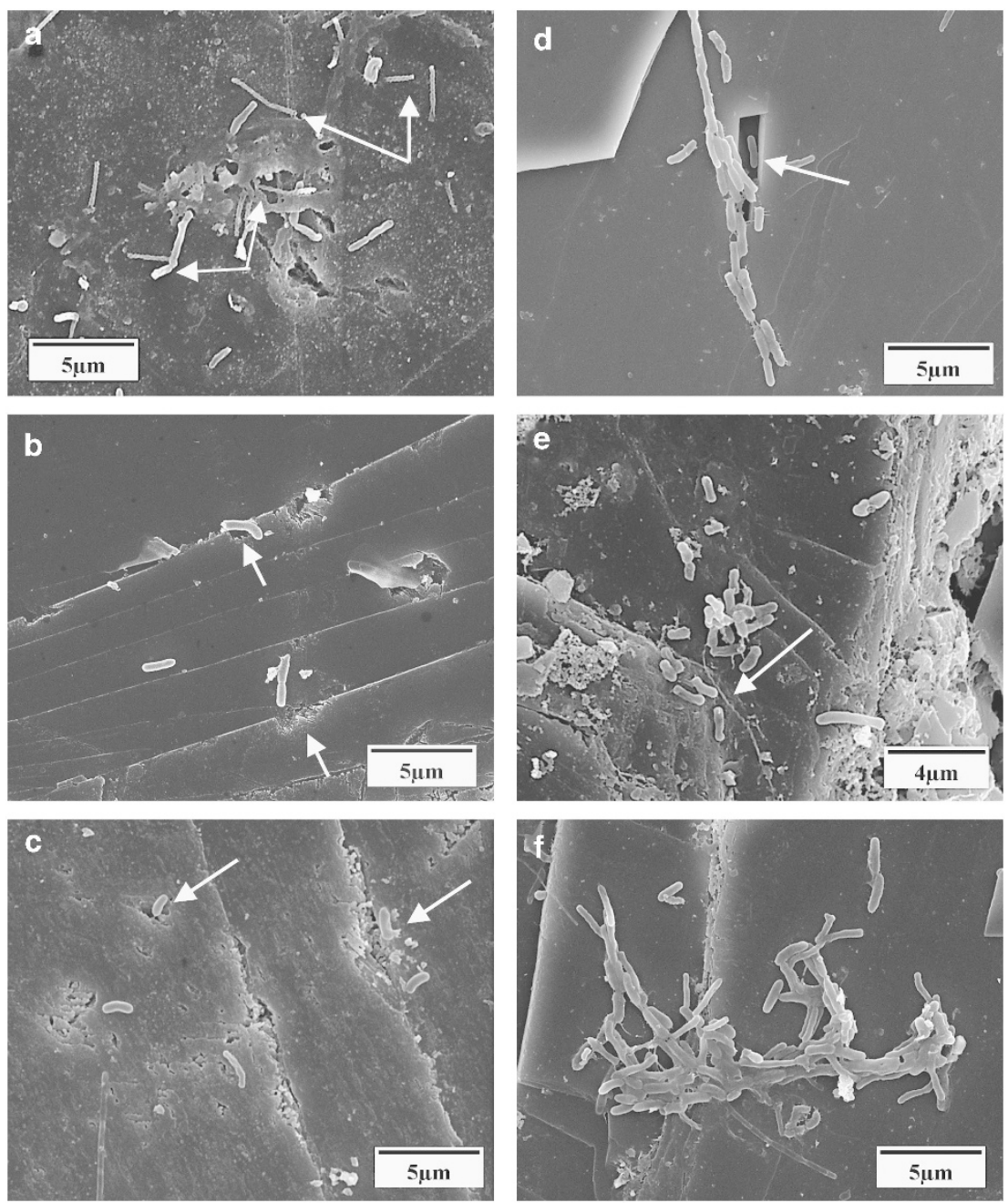

Figure 5 Scanning electron photomicrographs of cell morphologies, cell clusters and dissolution features on calcite (a-c) and dolomite (d-f) mineral surfaces from in situ microcosms deployed in Edwards Aquifer wells for 26 days. All scale bars except (e) are at $5 \mu \mathrm{m}$; (e) is at $4 \mu \mathrm{m}$. (a) Arrows point to cells with unique 'corkscrew' morphology from LCRA Deep, (b) single cells associated with dissolution along cleavage surfaces from LCRA Shallow and (c) also from Paradise Alley Shallow. (d) Chain of cells from LCRA Shallow, (e) associated with dissolution in Girl Scout Deep and (f) cells clusters associated with cleavage surfaces in LCRA shallow.

results could be interpreted from the viewpoint of potential dependence on, or metabolic production of, a compound. For instance, Gammaproteobacteria and Deltaproteobacteria were strongly associated with saline wells and correlated to CCA axis 1. But, Gammaproteobacteria potentially utilize sulfide and decrease alkalinity if metabolizing as chemolithoautotrophs (Rossmassler et al., 2012), and Deltaproteobacteria are well-known sulfate reducers that generate sulfide and can increase alkalinity if they metabolize chemoorganotrophically. As such, both of these groups have the potential to affect carbonate geochemistry and mineral solubility. When extrapolating these results to the full community composition per well, a range of putative chemolithoautotrophic communities are prevalent from saline wells, including Halothiobacillaceae (Chromatiales) that aerobically oxidize reduced sulfur compounds (Kelly and Wood, 2000), uncultured Epsilonproteobacteria and Hydrogenophilales
(Thiobacillus spp.). Thiobacilli are perhaps the beststudied sulfur-oxidizing bacteria (Friedrich et al., 2005). In contrast, potential heterotrophic and chemoorganotrophic indicator taxa in freshwater wells correlated to dissolved oxygen and included the Caulobacterales, which are aerobic, oligotrophic aquatic bacteria with a high degree of metabolic versatility (Boone et al., 2001), Sphingomonadales, which have wide metabolic capabilities (Frederickson et al., 1995), and Rhizobiales, which are ecologically diverse, important in biofilm formation under oxic and anoxic conditions, and are even capable of oxidizing reduced sulfur (Masuda et al., 2010). Other groups include the Pseudomonadales, which are classic examples of respiring chemoorganotrophs with simple nutritional requirements (Spiers et al., 2000), and Burkholderiales, which are metabolically versatile chemoorganotrophs also capable of $\mathrm{N}_{2}$ fixation or denitrification (Saito et al., 2008). From these interpretations, there 
is evidence that microbially produced acidity resulting from reduced sulfur compound oxidation and chemolithoautotrophic uptake of inorganic carbon could induce carbonate dissolution in saline portions of the aquifer, but that carbonic acid evolved from $\mathrm{CO}_{2}$, more likely originating from organic carbon degradation and respiration, could enhance carbonate dissolution in fresh water. Therefore, although microbially promoted carbonate dissolution is enhanced by the local decrease in $\mathrm{pH}$ at the cell-mineral interface (see, e.g., Sjoberg and Rickard, 1984; MacInnis and Brantley, 1992), the results from our study demonstrate that microbes responsible for dissolution, and the nature of carbonate dissolution, across the fresh to saline water transition zone differ as a function of the changing geochemistry.

Finally, probably the most significant conclusion from this study is that carbonate dissolution in the freshwater portion of the aquifer is potentially greater than in the sulfidic section. This might be a surprising result when contrasted against previous investigations of microbially mediated carbonate dissolution from sulfidic caves (Engel et al., 2004; Steinhauer et al., 2010). But, in those studies, any potential heterotrophic contribution to carbonate dissolution was masked because sulfur-oxidizing bacterial groups extensively colonized the experimental surfaces or were the intended focus of the investigation. Furthermore, when considering the dissolution differences between the fresh and saline waters, and although our work was done at a local scale, it could be possible to extrapolate the findings to the larger, more regional scale. There are significant differences in permeability and transmissivity between the fresh and saline portions of the aquifer, which could be the consequence of changes in microbial activity and colonization of carbonate surfaces. In conclusion, this work expands our understanding of microbial diversity in karst aquifers and emphasizes the importance of evaluating and quantifying active microbial processes that could affect carbonate weathering in the subsurface. The results have important implications for investigations related to carbon sequestration and storage (see, e.g., Mitchell et al., 2009; Kirk, 2011) and groundwater and drinking water resources (see, e.g., Stein et al., 2010; Smith et al., 2011). Accordingly, to fully appreciate diverse microbial communities and carbonate geochemistry, more experimental research is needed from freshwater segments of karst aquifers and caves, and the potential role of microbes in affecting karst aquifer hydraulic properties (for example, porosity, transmissivity) should also be considered.

\section{Conflict of Interest}

The authors declare no conflict of interest.

\section{Acknowledgements}

We recognize Geary Schindel (and the Edwards Aquifer Authority) for access to study wells. Numerous members of the Engel lab assisted in the field and laboratory analyses. We thank three anonymous reviewers for their constructive comments to improve the paper. This research was funded to CJG by an American Association of Petroleum Geologists Foundation student grant, the William L. Wilson Scholarship from the Karst Waters Institute and the Louisiana State University Department of Geology and Geophysics, and to ASE by the Louisiana Board of Regents (LEQSF(2006-2009)-RD-A-03) and the Jones Endowment for Aqueous Geochemistry at the University of Tennessee-Knoxville.

\section{References}

Anderson MJ. (2001). A new method for non-parametric multivariate analysis of variance. Austral Ecol 26: 32-46.

Besemer K, Peter H, Logue JB, Langenheder S, Lindström ES, Tranvik LJ et al. (2012). Unraveling assembly of stream biofilm communities. ISME J 6: 1459-1478.

Birdwell JE, Engel AS. (2009). Variability in terrestrial and microbial contributions to dissolved organic matter fluorescence in the Edwards Aquifer, Central Texas. J Cave Karst Stud 71: 144-156.

Boone DR, Garrity GM, Castenholz RW, Brenner DJ, Krieg NR, Staley JT. (2001). Bergey's Manual of Systematic Bacteriology. Springer: New York, NY, USA, 1388pp.

Clement TJ, Sharp JM. (1988). Hydrochemical Facies in the Bad-Water Zone of the Edwards Aquifer, Central Texas. National Water Well Association: Dublin, $\mathrm{OH}$, pp 127-149.

Cole JR, Wang W, Cardenas E, Fish J, Chai B, Farris RJ et al. (2009). The ribosomal database project: improved alignments and new toold for rRNA analysis. Nucleic Acids Res 37: D141-C145.

Compton RG, Pritchard KL. (1990). The dissolution of calcite at $\mathrm{pH}>7$ : kinetics and mechanisms. Phil Trans $R$ Soc Lond A 330: 47-70.

Davis KJ, Lüttge A. (2005). Quantifying the relationship between microbial attachment and mineral surface dynamics using vertical scanning interferometry (VSI). Am J Sci 305: 727-751.

Dowd SE, Sun Y, Wolcott RD, Domingo A, Carroll JA. (2008). Bacterial tag-encoded FLX amplicon pyrosequencing (bTEFAP) for microbiome studies: bacterial diversity in the ileum of newly weaned Salmonellainfected pigs. Foodborne Pathog Dis 5: 459-472.

Ehrlich HL, Newman DK (eds) (2009). Geomicrobiology. CRC Press Taylor \& Francis Group: Boca Raton, FL.

Engel AS, Meisinger DB, Porter ML, Payn R, Schmid M, Stern LA et al. (2010). Linking phylogenetic and functional diversity to nutrient spiraling in microbial mats from Lower Kane Cave (USA). ISME J 4: 98-110.

Engel AS, Randall KW. (2011). Experimental evidence for microbially mediated carbonate dissolution from the saline water zone of the Edwards Aquifer, Central Texas. Geomicrobiol J 28: 313-327.

Engel AS, Stern LA, Bennett PC. (2004). Microbial contributions to cave formation: new insight into sulfuric acid speleogenesis. Geology 32: 369-372. 
Ford DC, Williams P. (2007). Karst Hydrology and Geomorphology. Wiley: Chichester, West Sussex, England, 576pp.

Frederickson JK, Balkwill DL, Drake GR, Romine MF, Ringelberg DB, White DC. (1995). Aromatic-degrading Sphingomonas isolates from the deep subsurface. Appl Environ Microbiol 61: 1917-1922.

Friedrich CG, Bardischewsky F, Rother D, Quentmeier A, Fischer J. (2005). Prokaryotic sulfur oxidation. Curr Opin Microbiol 8: 253-259.

Fuhrman JA, Comeau DE, Hagström Å, Chan AM. (1988). Extraction from natural planktonic microorganisms of DNA suitable for molecular biological studies. Appl Environ Microbiol 54: 1426-1429.

Griebler C, Lueders T. (2009). Microbial biodiversity in groundwater ecosystems. Freshwater Biol 54: 649-677.

Groscehen GE, Buszka PM. (1997). Hydrogeologic framework and geochemistry of the Edwards aquifer salinewater zone, south-central, Texas. U.S. Geological Survey Water Resource Investigation 97-4133, 47pp.

Guyton WF and Associates. (1979). Geohydrology of Comal, San Marcos, and Hueco Springs. Texas Department of Water Resouces Report 234.

Hammer Ø, Harper DAT, Ryan PD. (2001). PAST: Paleontological Statistics software package for education and data analysis. Palaeontol Electron 4: 9. http://palaeoelectronica.org/2001_1/past/issue1_01.htm.

Hiebert FK, Bennett PC. (1992). Microbial control of silicate weathering in organic-rich ground water. Science 258: 278-281.

Johnson S, Schindel G. (2008). Evaluation of the option to designate a separate San Marcos Pool for critical period management. Edwards Aquifer Authority Report No. 08-01, 117pp.

Kato K, Nagaosa K, Kimura H, Katsuyama C, Hama K, Kunimaru T et al. (2009). Unique distribution of deep groundwater bacteria constrained by geological setting. Environ Microbiol Rep 1: 569-574.

Kelly DP, Wood AP. (2000). Reclassification of some species of Thiobacillus to the newly designated genera Acidithiobacillus gen. nov., Halothiobacillus gen. nov. and Thermithiobacillus gen. nov. Int J Syst Evol Microbiol 50: 511-516.

Kirk MF. (2011). Variation in energy available to populations of subsurface anaerobes in response to geological carbon storage. Environ Sci Technol 45: 6676-6682.

Koterba MT, Wilde FD, Lapham WW. (1995). Ground-water data-collection protocols and procedures for the National Water-Quality Assessment program: collection and documentation of water-quality samples and related data. U.S. Geological Survey Open-File Report 95-399, Reston, VA, 123pp.

L'Haridon S, Miroshnichenko ML, Kostrikina NA, Tindall BJ, Spring S, Schumann P et al. (2006). Vulcanibacillus modesticaldus gen. nov., sp. nov., a strictly anaerobic, nitrate-reducing bacterium from deep-sea hydrothermal vents. Int J Syst Evol Microbiol 56: 1047-1053.

Land LS, Prezbindowski DR. (1981). The origin and evolution of saline formation water, lower Cretaceous carbonates, south-central Texas, USA. J Hydrol 54: 51-74.

Legendre P, Legendre L. (1998). Numerical Ecology, 2nd English edition. Elsevier: Amsterdam, The Netherlands, 853pp.

Legendre P, Borcard D, Peres-Neto PR. (2005). Analyzing beta diversity: partitioning the spatial variation of community composition data. Ecol Monograph 75: 435-450.

Liu Z, DeSantis TZ, Andersen GL, Knight R. (2008). Accurate taxonomy assignments from 16S rRNA sequences produced by highly parallel pyrosequencers. Nucleic Acids Res 36: e120.

Loáiciga HA. (2009). Long-term climatic change and sustainable ground water resources management. Environ Res Lett 4: 035004.

Loáiciga HA, Maidment DR, Valdes JB. (2000). Climatechange impacts in a regional karst aquifer, Texas, USA. J Hydrol 227: 173-194.

Longley G. (1981). The Edwards Aquifer: Earth's most diverse groundwater ecosystem? Int J Speleol 11: 123-128.

Lüttge A, Conrad PG. (2004). Direct observation of microbial inhibition of calcite dissolution. Appl Environ Microbiol 70: 1627-1632.

MacInnis IN, Brantley SL. (1992). The role of dislocations and surface morphology in calcite dissolution. Geochim Cosmochim Acta 56: 1113-1126.

Martin JB, White WB (eds). (2008). Frontiers of Karst Research, Special Publication 13. Karst Waters Institute: Leesburg, VA, 118pp.

Masuda S, Eda S, Ikeda S, Mitsui H, Minamisawa K. (2010). Thiosulfate-dependent chemolithoautotrophic growth of Bradyrhizobium japonicum. Appl Environ Microbiol 76: 2402-2409.

Mitchell AC, Phillips AJ, Hiebert R, Gerlach R, Spangler LH, Cunningham AB. (2009). Biofilm enhanced geologic sequestration of supercritical $\mathrm{CO}_{2}$. Int $J$ Greenh Gas Con 3: 90-99.

Musgrove M, Fahlquist L, Houston NA, Lindgren RJ, Ging PB. (2009). Geochemical evolution processes and water-quality observations based on results of the National Water-Quality Assessment Program in the San Antonio segment of the Edwards aquifer, 19962006. U.S. Geological Survey Scientific Investigations Report 2010-5129, 93pp.

Oetting GC, Banner JL, Sharp JM. (1996). Regional controls on the geochemical evolution of saline groundwaters in the Edwards Aquifer, central Texas. J Hydrol 181: 251-283.

Pronk MN, Goldscheider N, Zopfi J. (2009). Microbial communities in karst groundwater and their potential use for biomonitoring. Hydrogeol J 17: 36-48.

Ramette A. (2007). Multivariate analyses in microbial ecology. FEMS Microbiol Ecol 62: 142-160.

Rogers JR, Bennett PC, Choi W. (1998). Feldspars as a source for microorganisms. Am Mineral 83: 1532-1540.

Rossmassler K, Engel AS, Twing KI, Hanson TE, Campbell BJ. (2012). Drivers of epsilonproteobacterial community composition in sulfidic caves and springs. FEMS Microbiol Ecol 79: 421-432.

Rye RO, Back W, Hanshaw BB, Rightmire CT, Pearson FJ Jr.. (1981). The origin and isotopic composition of dissolved sulfide in groundwater from carbonate aquifers in Florida and Texas. Geochim Cosmochim Acta 45: 1941-1950.

Saito T, Ishii S, Otsuka S, Nishiyama M, Senoo K. (2008). Identification of novel Betaproteobacteria in a succinate-assimilating population in denitrifying rice paddy soil by using stable isotope probing. Microbes Environ 23: 192-200.

Shabarova T, Pernthaler J. (2010). Karst pools in subsurface environments: collectors of microbial diversity or 
temporary residence between habitat types. Environ Microbiol 12: 1061-1074.

Sharp JM, Banner JL. (1997). The Edwards Aquifer: a resource in conflict. GSA Today 7: 1-9.

Sjoberg EL, Rickard DT. (1984). Calcite dissolution kinetics: surface speciation and the origin of the variable $\mathrm{pH}$ dependence. Chem Geol 42: 119-136.

Smith RJ, Jeffries TC, Roudnew B, Fitch AJ, Seymour JR, Delpin MW et al. (2011). Metagenomic comparison of microbial communities inhabiting confined and unconfined aquifer ecosystems. Environ Microbiol, Doi:10111/j1462-2920201102614x.

Spiers AJ, Buckling A, Rainey PB. (2000). Mini review: the causes of Pseudomonas diversity. Microbiol Mol Biol Rev 146: 2345-2350.

Stein H, Kellermann C, Schmidt SI, Brielmann H, Steube C, Berkhoff SE et al. (2010). The potential use of fauna and bacteria as ecological indicators for the assessment of groundwater quality. J Environ Monit 12: 242-254.

Steinhauer ES, Omelon CR, Bennett PC. (2010). Limestone corrosion by neutrophilic sulfur-oxidizing bacteria: a coupled microbe-mineral system. Geomicrobiol J 27: 723-738.

Sun Y, Wolcott RD, Dowd SE. (2011). Tag-encoded FLX amplicon pyrosequencing for the elucidation of microbial and functional gene diversity in any environment. In: Kwon YM, Ricke SC (eds). HighThroughput Next Generation Sequencing: Methods and Applications (Methods in Molecular Biology). Springer: New York, NY, USA, pp 129-141.

US Geological Survey(variously dated). National field manual for the collection of water-quality data: U.S. Geological Survey Techniques of Water-Resources Investigations, book 9, chaps. A1-A9, available online at http://pubs.water.usgs.gov/twri9A.

Vandevivere P, Bevaye P. (1992). Sampling method for the observation of microorganisms in unconsolidated porous media via scanning electron microscopy. Soil Sci 153: 482-485.

White WB. (2002). Karst hydrology: recent developments and open questions. Eng Geol 65: 85-105.

White WB. (1997). Thermodynamic equilibrium, kinetics, activation barriers, and reaction mechanisms for chemical reactions in karst terrains. Environ Geol 30: 46-58.

Wood WW. (1981). Guidelines for collection and field analysis of ground-water samples for selected unstable constituents. U.S. Geological Survey Techniques of Water-Resources Investigations of the United States Geological Survey Book 1, Chapter D2, 24pp.

Supplementary Information accompanies the paper on The ISME Journal website (http://www.nature.com/ismej) 